\title{
5 Mo's challenge. Waiting and the question of methodological nationalism
}

\author{
Kari Anne Drangsland
}

\section{Introduction}

A sunny afternoon in November 2017, Mo and I took one of our many walks in a park adjacent to the asylum camp where he was living in Hamburg. Mo, an Afghan man in his early twenties, had waited for 2 years for the answer to his asylum application. As we strolled along, he spoke about his longing to meet his family who lived in Iran and how he feared deportation to Afghanistan - a country he had never seen. He was 'constantly thinking about the future,' and about how he might 'solve his problems,' as he put it. 'Kari, I believe I am slowly going crazy,' he said. At that point, I feared for his life. 'Do you have an advice for me?' he asked. I felt a desire to provide some form of comfort, to give some advice. 'What about vocational training?,' I said, albeit hesitantly. 'You know ... there is this possibility ... with vocational training, you can stay.' Walking next to me, Mo sounded upset as he said: 'But I cannot do it. My mother needs money so badly now. I must work. I cannot wait three years.'

The aim of this chapter is twofold. First, I wish to address some epistemological challenges that emerge upon using waiting as an analytical lens in ethnographic research on irregular migration. Second and consequent, I want to think about ways to engage with these challenges analytically. Particularly, I explore how the temporal logic of waiting as an analytic optic intersects with the territorial imaginary of methodological nationalism; that is, the assumption that the nation-state is the natural political and social form of the modern world (Glick Shiller \& Wimmer, 2002: p. 301). Waiting, as a temporal imaginary, tends to be structured in terms of an orientation towards an anticipated and awaited future (object). Due to this temporal structure, I suggest, the imaginary of waiting risks enforcing a conceptualisation of the present in terms of lack. With 'lack,' I mean to capture how the present comes to be thought in terms of incompleteness in relation to the suspended and awaited future to which it tends. I argue that this structure makes the analytical lens susceptible to reinforcing methodological nationalism when it is used in ethnographic research on irregular migration. I suggest, that to further the critical potential of waiting as an analytical 
lens, waiting should be conceptualised in terms of temporal heterogeneity and relationality.

The scene opening this chapter took place during an ethnographic fieldwork I conducted in Hamburg, Germany, from 2017 to 2018. I moved to Hamburg in August 2017, as part of an interdisciplinary project, researching European border practices and the conditions of irregular migrants through the analytical lens of 'waiting,' thus forming part of a growing body of research on waiting and migration (Conlon, 2011; Andersson, 2014: p. 166; Bagelman, 2016; Jacobsen and Karlsen, 2020). In the autumn of 2017, German migration discourse was marked by the growth of the nationalist party (Alternative für Deutschland) and political struggles in the aftermath of the increase in numbers of asylum seekers in 2015 and 2016. Between 2015 and 2017, the German Parliament issued around 20 bills in the field of migration legislation (Forum Menschenrechte, 2019), which to a large extent curtailed the rights of asylum seekers and raised the required threshold for granting asylum statuses. Young, male, single and healthy Afghans, such as Mo, had little possibility of being granted with asylum in Germany. However, Germany's migration policies have for years also been shaped through the state's concern with demographic change and labour shortage (Sekino, 2010; Castañeda, 2012; Schultz, 2018). In 2016, with the new Integrationsgesetz (Integration Act), the German government opened for the possibility that some categories of rejected asylum seekers could receive a long-term Duldung, that is, a temporary suspension of deportation, if they started Berufsausbildung (vocational training, in short: Ausbildung). The regulation came with the possibility of a temporary residence permit for those who manage to successfully complete training (usually after 3 years). The Ausbildungsduldung implies years of deportability, a standing prohibition against travelling abroad, and the ruling out of family reunification. However, in 2017, people working with asylum seekers whose applications were denied began to understand the category of Ausbildungsduldung as a longed for, albeit tough, solution; a way out of the precarious condition of irregularity and deportability (Scherschel, 2016; Will, 2018; Drangsland, 2020). It was within this context that I suggested Ausbildung as a solution to Mo's 'problems,' as he put it. Responding to his hardship, I reached out for and conjured up a trajectory to a future where he could 'stay' in Germany. However, Mo rejected my advice with a reference to an urgent 'now,' pointing out how training means a suspension of work-income: 'My mother needs money so badly now.'

My point of departure for this chapter is Mo's rejection of my suggestion that he started training. Our conversation prompts a critical question: From which awaited future do I envision Mo's 'now' and what are the ramifications of this temporal positioning to my understanding of his life? ${ }^{1}$ In this chapter, I first approach Mo's answer as a challenge to think through how methodological nationalism informs waiting as an analytical lens in ethnographic work. Importantly, my response to Mo highlights 
how spatiotemporal imaginaries, such as methodological nationalism, or indeed, waiting, are never solely a matter of thought or contemplation alone. Rather, they are performed and practiced in fieldwork as scholars observe and take part in migrants' struggles for their rights and the possibility to build a liveable life (De Genova, 2013b). Second, I approach Mo's challenge as a call to be attuned to the complexity and heterogeneity of the 'now' of the people whose lives researchers scrutinise through the lens of 'waiting.'

I will elaborate my argument and methodological prism in several stages. First, I will supply an account of the research on which I base my discussion and provide some methodological considerations. Afterwards, I discuss the critique of methodological nationalism in migration research (Wimmer \& Glick Schiller, 2002; De Genova, 2013b) in relation to some core conceptual features of waiting. I argue that the temporal structure of waiting, with its configuration of the present as a 'lack' in relation to an awaited future, might enforce a reductive understanding of irregular migrants' struggles and reinforce a notion of a benevolent state. In the subsequent sections, I tune into the stakes of Mo's answer, while also drawing on other fieldwork encounters. In that respect, 'Mo's challenge,' which was the starting point of this chapter, also stands for the general challenge of listening carefully to people. Drawing on the work of historian Chakrabraty (2000) and geographer Massey (2005), I argue that the task of analysing the practices and experiences of my interlocutors requires opening the lens of waiting to temporal heterogeneity and relationality. Temporal heterogeneity, in this context, involves, on the one hand, an understanding of people as immersed in multiple and co-constitutive temporalities. I show in this chapter how such temporalities play out on different scales, such as the scale of international politics, and at the embodied, daily 'microlevel' (Mountz \& Hyndman, 2006: p. 447) of migrants' experiences. On the other hand, the lens of temporal heterogeneity involves recognising how the 'now' of things, places and peoples' lives are imbued with change, in the sense of being, as Massey puts it, 'a constellation of processes' (Massey, 2005: p. 141). Such an approach opens the lens of waiting to multiple and interrelated futures and thus complicates any story of waiting as tending towards a foretold end that is spatialised as reinsertion into the nation-state. By showing how the experience of waiting is shaped through a sense of life as not waiting - that is, how the 'now' of waiting is relationally lived and imbued with change - I argue furthermore, that rethinking waiting in terms of temporal heterogeneity might further its potential as a lens for critique of present bordering practices.

\section{Research context and some methodological considerations}

My analysis is based on 11 months of ethnographic fieldwork in Hamburg (August 2017 to June 2018), and on subsequent contact with eight of my interlocutors in the following years. I also draw on fieldwork conducted in southern Germany in April 2017. 
I met most of my interlocutors in two asylum camps, or so-called Erstaufnahmeeinrichtungen (EAE). EAE camps provide provisional housing, often barracks. In 2017, asylum seekers were obliged to stay in such camps during their first 6 months in Germany. Yet, Hamburg was coping with the increase in the number of asylum seekers in 2015 and 2016, and the average time of residency in EAE camps in 2017 was longer (Zentraler Koordinierungsstab Flüchtlinge, 2017). At the time of my fieldwork, some of my interlocutors, including Mo, have been living in such camps for more than 18 months. The majority of my interlocutors in the camps were Syrian families or men with a Dublin decision or a Duldung status, as well as male Afghan asylum seekers who were either awaiting their asylum decision or holding a $\mathrm{Dul}$ dung. $^{2}$ As this account may testify, the vast majority of the inhabitants in the camps were men. I also got in contact with people through two humanitarian organisations working with irregular migrants. The people I met in these arenas were mostly from Ghana or other West African countries and were either holding a Duldung or living unauthorised in Germany.

Since I contextualise my discussion in relation to the German Ausbildungsduldung, this legal construct needs some explanation. The Duldung is not a residence permit but prescribes a temporary suspension of deportation (normally 3-6 months), due to legal, humanitarian or factual reasons. It can be renewed, and many live in this condition for years. Studies have highlighted the Duldung as a condition of rightlessness, uncertainty and social stigma (Castañeda, 2010; Mitrić, 2013; Drangsland, 2019; Herbert Brücker, 2019). As opposed to this finding, state and humanitarian actors have tended to frame the 2016 Ausbildungsduldung as providing migrants with future prospects (Drangsland, 2020). Its novelty was that it prescribes that appropriate training might provide the 'tolerated' (geduldet) migrant with a legal right to a suspension of deportation for the full duration of training. Furthermore, upon successful completion of the training period migrants acquire the right for a 2-year work-related residence permit, with the possibility of renewal. However, the 2016 Ausbildungsduldung was not given to Dublin migrants, or (with some exceptions) to people from so-called secure third countries. Thus, it excluded most of my Syrian and Ghanaian interlocutors. ${ }^{3}$ My conversation with Mo highlights young and able Afghans as a target group for the Ausbildungsduldung in Hamburg. ${ }^{4}$ Germany had, with some exception, stopped most deportations to Afghanistan in 2017 (Pro Asyl, 2019). Afghans, when receiving their deportation decision would thus also receive a Duldung. As was the case for Mo, this form of Duldung would (with some exceptions) give the right to a restricted work permit (Voigt, 2020).

Before I move on, two clarifications are required. First, to secure their anonymity, I have changed my interlocutors' names and slightly altered features of their biographies, including the spatiotemporal markers of our encounters. Second, there is a need to be clear about the different situations for people waiting for an asylum decision and for those outside the asylum 
institution. On the one hand, my interlocutors in the camp, including Mo, commonly used the German verb warten (wait) to describe the exhausting situation of awaiting the asylum application decision. My West African interlocutors, on the other hand, seldom referred to their situation in terms of 'waiting' but rather described it as a condition of 'struggling,' thereby narrating their present situation as part of a life-long struggle for a viable life. ${ }^{5}$ The majority had years of migration behind them, often in precarious material and legal conditions.

These differences highlight 'waiting' as a diverse condition. Importantly however, also the Afghans with whom I spent time often described their lives in Afghanistan or Iran in terms of struggling to make do in the context of an uncertain future. A topic of our conversation was how, for some interlocutors, the present condition in Hamburg formed part of a generalised condition of uncertainty. As Ali, a young Afghan man, once said: 'My problem here is the same as in Afghanistan: An uncertain future.' This sense of generalised uncertainty recalls Vigh's (2008) argument regarding the Western conception of 'crisis' as an exceptional condition. Drawing on fieldwork in Guinea-Bissau, Vigh describes how crisis becomes a context of life, which forces people to "make lives in fragmented and volatile worlds rather than waiting for normalisation and reconfiguration' (2008: p. 8). By reading the notion of waiting through a lens of relational space and temporal heterogeneity, I seek to nuance the understanding of how waiting is experienced and practiced and, furthermore, the conceptualisation of waiting as a state that tends towards 'normalisation,' which, when the research object is irregular migration, often is spatialised in terms of reinsertion into a territorial, national order.

\section{Methodological nationalism and waiting's 'not yet'}

In their seminal text on methodological nationalism in the social sciences, Glick Schiller and Wimmer contend that 'nation building, the control and restriction of immigration and the rise of a social science preoccupation with migration are interlinked processes' (2002: p. 302). They argue for the need to scrutinise the epistemological ramifications of the predominant assumption within migration research 'that the nation/state/society is the natural social and political form of the modern world' (Wimmer \& Glick Schiller, 2002: p. 301). Additionally, they criticise migration research for inattentiveness to nationalism and its effect on nation-building processes and argue that empirical research tends to be circumscribed by the territorial boundaries of nation-states. Within the German context, Hess (2015) has shown how methodological nationalism operates in research on 'guest workers' and migrant integration to essentialise migrant identities and naturalise national (and racialised) policy concerns. In a similar vein, De Genova $(2002,2013 a)$ has shown how methodological nationalism works to naturalise migrant illegality and conceal its political and legal production. 
In this often-unexamined spatial imaginary, the refugee and the irregular migrant are positioned as a problem and denied, as Arendt (1967) argues, rights and protection. Through writing and fieldwork practices, De Genova argues, researchers participate, unwittingly or consciously, 'in the very same socio-political processes and struggles through which the "national" configuration of "society" (or, the social field) is reified" (2013b: p. 251). He calls for a self-reflexive critique of how research "contributes to the ongoing nationalisation of "society" (2013b: p. 252).

One researcher who has taken up the call to think critically about how methodological nationalism informs research that takes migrants' waiting as its object of study and analytical lens is the anthropologist Ramsay (2017). Exploring humanitarian and policy discourses on migrants' protracted waiting in refugee camps, she argues that these discourses narrate migrants' displacement and waiting as a story that 'begins at exodus, when refugees lose the national identity of their origin country, and is resolved when the refugee is once again re-inserted into a context of national identification' (Ramsay, 2017: p. 18). This one-directional temporal logic, she argues, also pervades research literature, with consequences for how policy and migrants' experiences are analysed. Drawing amongst others on Vigh's (2008) critique of the exceptionalism that pervades scholarly work on crisis, she argues that displacement tends to be conceptualised, as a 'a juncture in time, as a condition of temporal liminality in which refugees and other kinds of irregular migrants are seemingly permanently suspended in the immediacy of the present' (Ramsay, 2017: p. 18). To her, the metaphor of 'liminality,' used in anthropology to capture transitional rites, signals a logic of temporal linearity and transition. It might, she suggests, reinforce a conception of migration as a crisis in relation to the normal (national) social fabric. Through ethnographic work with migrant displacement and resettlement programs to Australia, she (2017) shows how this logic reduces the complexity of migrants' lives and reproduces instead a notion of a benevolent state as the redemptive endpoint to waiting (see also Drangsland, 2019).

Ramsay' argument recalls the work of scholars such as Salih and RichterDevroe (2018) and Malkki $(1995,2012)$ who, through empirical work with Palestinian refugees and with Hutu refugees in Tanzania, show how the organising logic of territorial nation-states informs thinking about displacement, statelessness and dispossession. All these three scholarly works highlight how methodological nationalism functions, in thinking and writing, as a 'chronotopic' (Bakthin, 1981) imaginary; that is, an imaginary that performs and 'project[s] premises about' (Kelly, 1998: p. 843) ways of thinking space and time, including people's presents and futures. In other words, to paraphrase Kelly's discussion of the large-scale chronotopic imaginaries of modernity and globalisation, methodological nationalism 'establish[s] space-time possibilities' (Kelly, 1998: p. 843; see also Klinke, 2013). In relation to migrant displacement, methodological nationalism operates to conjure up a trajectory that tends towards a future 'that already 
is foretold' (Massey, 2005: p. 68) as reinsertion into 'the national order of things' (Malkki, 1995: p. 495).

What I want to draw attention to in the following, and thus changing the gaze somewhat, is how the analytic optic of waiting carries with it some conceptual features, which, I argue, make it susceptible to reinforcing methodological nationalism. This focus is important, because while waiting often is deployed to investigate the temporal dimensions of borders and migration, how time is thought is often left implicit. Consequently, waiting's chronotopic functions remain unexplored. Since I am unable to provide a thorough analysis of the conceptual 'baggage' (Desjarlais, 1997: p. 11) of waiting in this short essay, I will merely point to two interrelated features that tend to characterise waiting as a temporal imaginary to make my argument. These are the orientation of waiting 'towards' (or, perhaps rather 'from') an awaited future; and a related conceptualisation of the present in terms of lack and incompleteness in relation to this future.

\section{Waiting as a chronotopic imaginary}

Tracing the etymology of the verb 'to wait' from the German meaning to guard and the French meaning to watch, Bissell shows how the verb suggests 'a sense of anticipatory preparedness - a lying-in-wait-for' (2007: p. 282). Drawing from this, he argues that an understanding of waiting as some form of anticipation is common within Western thought. Waiting, he contends, is often seen as brought about and necessitated by 'the promise' of an 'event-to-come' (Bissell, 2007: p. 282; see also Rotter, 2016). This temporal configuration, he notes, is visible both within eschatological conceptualisations of waiting (see also Vanstone, 2006) and within research literature that is underpinned by the linear temporal model associated with capitalism. Within the latter temporal model, waiting generally, as Lahad (2017) observes, carries negative associations and is understood as a 'wasted' time that should be eliminated or minimised for the sake of a more productive time.

Visible here, I suggest, is how waiting, as a chronotopic concept, tends to be oriented towards a still absent future (its anticipated end). This temporal structure also underlies Bourdieu's thinking about waiting and power on which many (migration) scholars have fruitfully drawn (Jeffrey, 2008; Hage, 2009; Auyero, 2011; Bagelman, 2016). Waiting is a relation to time where 'we anticipate the future as too slow in coming,' Bourdieu (2000: p. 209) argues, quoting Pascal. Bourdieu's work on waiting highlights that intrinsic to conceptualisations of waiting's 'now' (the state of anticipation) is its configuration in terms of some form of lack in relation to, absence of or distance from the awaited future. Indeed, when Bourdieu, discussing waiting as form of power, notes that destroying hope implies 'killing the waiting itself' (Bourdieu, 2000: p. 228), or when Crapanzano states that in waiting the world's 'only meaning lies in the future - in the arrival or non-arrival of the 
object of waiting' (in Rotter, 2016: p. 81), they highlight an imaginary that posits the 'now' as analytically meaningful solely in relation to the awaited (hoped for) object or future. In other words, waiting's 'now' becomes legible as the 'not yet' of the awaited future (waiting's end). ${ }^{6}$

It should be noted here that thinking the present as a relation to the future means different things for scholars, such as Bourdieu and Crapanzano, given the underpinning conceptualisations of time (Hodges, 2008; Pedersen, 2012). Bissell's work (2007), for example, highlights that while 'waiting' within mobility studies is thought in terms of temporal linearity, the concept also often implies a messianic temporality (see also Vanstone, 2006). Often however, as Ramsay (2017) notes, the underpinning conceptualisations of time are left implicit in work on waiting. My concern is that, as far as its temporal structure and chronotopic function are left implicit, the analytic optic of waiting risks enforcing a reading of the present in terms of lack when applied in ethnographic research. This is so, because while the awaited future (waiting's 'end') already figures in its 'now,' it has still not 'arrived.' In other words, in the chronotope of waiting, the 'now' remains a condition of incompleteness in relation to the awaited future that it tends towards. When waiting is used as lens in empirical research, it thus matters how the future is imagined and spatialised.

\section{Practicing the spatiotemporal imaginary of waiting in fieldwork}

My interest here is what happens when the chronotopic imaginary of waiting is deployed as a lens in empirical research. In order to answer this question, I believe, we must acknowledge how researchers not only practice their (our) spatiotemporal imaginaries when writing up the analysis (Massey, 2005). Indeed, spatiotemporal imaginaries are also practiced in embodied and affective fieldwork encounters in contexts where (political) nationalism materialises through law and policy. As De Genova argues, 'the dilemma of methodological nationalism is never simply a matter of not thinking critical enough' (2013b: p. 251, my italics). Faced with irregular migrants' struggles in conditions of deportability and violence, researchers reach out for and temporalise time in relation to available futures (Bourdieu, 2000). Such futures are currently possible, as Hage (2003: p. 15) has noted, primarily within national societies that work as mechanisms for the distribution of a dignified and meaningful social life. In this context, waiting, as a chronotopic imaginary, is spatialised in particular ways, and concepts such as delay, immobility and movement acquire normative meanings.

My encounter with Mo might illustrate this point. When I conjured up the future horizon of training, I took part in a broader societal discourse on the Ausbildungsduldung. As I have detailed elsewhere (Drangsland, 2020), the predominant discursive framing of the Ausbildungsduldung in 2017 was as a possibility and hope for tolerated migrants. In public and humanitarian discourses, it was coded as future oriented and in terms of activity 
(training) and movement towards a secure and viable life in Germany. As Mitrić (2013) argues, the Duldung is more than a regulation. It is a form of chronotopic 'storytelling in which the state narrates itself' (2013: p. 166) to constitute certain meanings and scenarios of belonging. However, while Mitrić shows how the Duldung as such has functioned to 'map' (2013: p. 134) the tolerated migrant as outside to, or rather, as 'suspended in' (2013: p. 134) the space and time of the German nation-state, the Ausbildungsduldung is structured, in public discourse, as a time of transition, through training, towards Aufenthalt. Illustratively of its temporal structure is how the Social Democratic Party (SPD), in the context of policy discourses on labour shortage and demographic change, has framed the Ausbildungsduldung in terms of Spurwechsel (lane-change) for (rejected) asylum seekers, that is, as a change of lane or tier from asylum to work on the journey towards the imagined end-station of Aufenthalt (residence permit) (SPD, 2018; Starzmann, 2018; Voigt, 2018; Walter, 2019). ${ }^{7}$ The future is, as Massey puts it, 'inscribed into the story' (2005: p. 68). This was also the story in which training could appear as solution to me. I seemed to have already known the future that was 'too slow in coming' for Mo. I approached his now, and his 'problems,' as he put it, as the 'not yet' of this (awaited) future: Training will enable him to move towards a secure future defined and spatialised through Aufenthalt.

Mo challenges such a reading of the Ausbildungsduldung in terms of movement. Defining training as a condition of waiting, his answer enhances and rearticulates the Ausbildungsduldung as a condition of delay and immobility. Importantly however, he does this by referring to a 'now' that 'cannot wait.' In other words, it is by highlighting how his 'now' is relational and configured in terms of movement and change that he makes the Ausbildungsduldung visible as a condition of waiting. Thereby, while his answer challenges an understanding of the Ausbildungsduldung in terms of movement, it at the same time complicates a reading of his waiting in terms of stasis and immobility. The challenge he posits to 'thinking waiting' recalls Chakrabarty's (2000) critique from a very different field; the critique of historical discourse. Arguing that academic historical reasoning positions contemporary people and places in a developmental process towards a foretold future 'whose theoretical subject [is] Europe' (Chakrabarty, 2000: p. 34), Chakrabarty shows that to read people's lives from the perspective of a foretold (known) future is conditional on an occlusion of the plurality of forms of belonging and temporalities people are immersed in. His work opens for an acknowledgement of the plurality of futures people envision for themselves, and that are practiced and produced as people live their lives in a web of spatiotemporal relations - relations that are, as Massey (2005) argues, always relations of power. Inspired by this critique, I address the challenge Mo poses as a challenge to read waiting against its 'one story' structure, forged within the nation-state frame - a story that might easily be creeping into writing. To paraphrase Vigh, what is at stake is a matter of 'freeing the concept from its temporal confines and thereby putting it to analytical use' (2008: p. 9). 


\section{A method of temporal heterogeneity}

Scholars have taken different steps to 'de-naturaliz[e] the national in research methodologies' (Amelina \& Faist, 2012: p. 1707). This includes, for example, different forms of transnational methodologies (Mountz, 2011; Casas-Cortes et al., 2015; Hess, 2015) and relational approaches to space (Amelina \& Faist, 2012). In relation to the spatiotemporal imaginary of waiting, this critique requires, to paraphrase Chakrabarty (2000: p. 45) again, displacing the nation-state from the centre towards which the time of waiting gravitates. This could be done in different ways. Ramsay's analytical move attempts to undermine the conception of citizenship as waiting's end. Studying her interlocutors' encounters with the Australian state, she shows how a sense of displacement and exclusionary practices endure after resettlement (Ramsay, 2017). Ramsay's move takes on salience in relation to Germany's extensive use of temporary residence permits, renewal of which, for some legal statuses, requires economic self-sufficiency. As one Nigerian man said, reflecting on the difference between his temporary residence permit and the previous Duldung (with a work permit): 'When you are recognised, it's also another race, it's like, you have to chase the paper, you know, like proving to them you want another year, by working... .' By referring to his struggle for papers as a 'race,' which awaken associations of competition, speed and exhaustion, he highlighted the continuous struggle to find work in a racialised labour market, and the precariousness of his inclusion (Karlsen, 2015), temporally, legally and materially, into the German state. It should be mentioned here, however, that when he talked about his life in Germany, he also stressed how his experiences formed part of a life-long struggle to make a viable life for himself in different locations. He narrated his life in Hamburg as part of a longer and open-ended journey: From struggling to find work as a young man in Accra, through years in Libya where he earned good money, to his flight to Europe in 2011 and subsequent years without secure work, legal status or family in Italy. While my focus in this chapter is on the future, this is a reminder of the meaning of the past for how people experience waiting (see, e.g. Hage, 2018). In that regard, a reductive reading of waiting's 'now' might not only be related to a conception of citizenship as waiting's end but also to an equation of waiting's beginning with the migrant's 'arrival' on a state territory.

I will, however, make another move to tune into the stakes of Mo's now stakes that, as Mo's answer indicates, evade understanding if his life is imagined primarily as tending towards an awaited future of Aufenthalt. This move implies rethinking the temporalities or temporal structure of waiting. As a response to 'Mo's challenge,' the questions I address in the rest of this chapter are: What is the potential for knowing if we address Mo's 'now' through an analytical lens (waiting) that starts out with its relational character, that is, how his now is also his mother's now? What happens if we address waiting (object of study) through a notion of temporal heterogeneity 
and how might this move challenge methodological nationalism? Asking these questions, I am inspired by Chakrabarty (2000) and Massey (2005), who from their different perspectives within postcolonial history and feminist geography, argue that questioning teleological narratives, such as modernity or globalisation, necessarily implies questioning the underpinning conceptions of time. While their respective objects of study were history and space, their works are useful for my purpose to think through the analytical optic of waiting in relation to the chronotopic function of methodological nationalism. This is so because in different ways these authors show how thinking time in terms of temporal heterogeneity and relationality challenges the tendency of scholars' analyses to, and here I paraphrase Chakrabarty, 'sum up [the] present[s]' (2000: p. 251) of people' struggles from the perspective of a foretold future, be it modernity, globalisation, or - as in the present case - a re-established national order. Their work is also a reminder that thinking about colonial others as 'waiting' to arrive in a future forged in the imaginary of the European nation-state carries racialised and essentialising normative assumptions (Chakrabarty, 2000: p. 8). ${ }^{8}$ If I am right that waiting easily entails a reading of migrants' now as a condition of lack in relation to a future of politico-legal inclusion (a future where the researcher often already is situated), their critique has relevance for my discussion: It is a reminder to question one's own 'speaking position' (Massey, 2005: p. 87) when telling stories about people waiting to 'enter' Europe.

\section{Mo's challenge: rethinking waiting's 'now'}

I first met Mo in August 2017 and then continued to see him on a weekly basis throughout my fieldwork. Although he hoped for a positive answer to his asylum application, his fear of deportation was intense, and he nervously followed news on German deportation flights to Afghanistan. Walking in the park that November day, when he said he feared he was 'going crazy,' I was worried by the pitch and tone of his voice. I knew he had stopped volunteering, stopped drawing, which he loved, and that he did not eat much. The young man, who had always lived with his family and from childhood worked long hours in a carpentry, was tired and exhausted by the 'cumulative stress' (Mountz, 2011: p. 388) of unemployment, loneliness and fear. To respond to his despair, I decided to point to the possibility of training, and, thereby, to conjure up a path to a future in Germany.

My response to Mo was surely affective and embodied. Nevertheless, as I have suggested to posit the Ausbildungsduldung as a solution presupposes a reductive reading of his now. At the least, it presupposes what Hage has called a 'labour of disentanglement' (2018: p. 204) of the different waiting(s) producing his condition. As Hage notes, when researchers 'produce one form of waiting as an ethnographic example, they surely must have already disentangled it from other forms of waiting it coexists with' (2018: p. 204). Thus, he argues, it is crucial that researchers make visible their analytical 
labour of disentanglement. What I want to point out here, however, is that the labour of disentanglement that make the Ausbildungsduldung appear as a solution, simultaneously implies an act that 'envelops other kinds of times' (Chakrabarty 2000: p. 16) and future horizons in the time of the Spur - the time defined through the German state and its economic interests (Mitrić, 2013; Drangsland, 2020). Mo's answer demonstrates that for him waiting for Aufenthalt was 'fused' (Hage, 2018: p. 204) with his mother's own waiting for him to send money. It was fused in ways that make full-time training (no work-income) undesirable as a solution.

When Mo rejects training on the grounds that 'he cannot wait,' he clearly refers to the obligation to provide for his family immediately. Mo's family, who at that time lived in Iran, struggled to make a living in the context of poverty and a precarious legal status (for research on Afghan migrants in Iran, see Christensen, 2016; Khosravi, 2017). Mo's obligation to send money highlights a general obligation prevalent amongst my Afghan and West African interlocutors, and underlines the usefulness of remittance as a lens from which to grasp migration as a transnational phenomenon (Nieswand, 2014). Mo's mentioning of his mother, however, captures a broader concern for his family that fused with his fear of deportation and the uncertainty regarding his legal status.

In 2018, two of Mo's siblings in Iran married. The expectation on Mo to contribute economically to their weddings became a core topic of our conversations, as did the sense of frustration and longing since he could not attend their weddings. Furthermore, their marriages implied that his aging parents would now be living alone, which raised his concerns. Then, in the spring of 2018, international occurrences gave a new dimension to his waiting. Mo used to show me his family pictures or newsfeeds of Taliban killings of Hazara people, the ethnic group to which he belonged, on his phone. In the spring 2018, he started showing me newsfeed articles quoting the president of the United States of America, Donald Trump, threatening Iran, in relation to Iran's nuclear program. Rising food prices throughout 2018 and 2019, in the context of the USA sanctions, affected Mo's family and put a pressure on him, affectively and economically, that fused with his navigations of awaiting the asylum decision and later (in the autumn of 2018) receiving the Duldung.

Mo's situation illustrates how 'the self is ultimately tied to the social,' as Vigh (2008: p. 15) puts it. Furthermore, his embodied condition of waiting appears as produced through relations spanning (and producing) spaces and spatiotemporal scales (as the scale of international politics, life course). Important to the argument here is Massey's (2005) insight that to acknowledge space and people's lives as produced through interrelations, that is, through 'interactions, from the immensity of the global to the intimately tiny' (2005: p. 9), opens up for thinking the 'now' (be it of a place, a thing, a subjectivity) as a constellation of a multiplicity of forms of living and temporalities 'which puls[ate] at different beats' (Massey, 2005: p. 158). The 'now' thus 
appears as heterogenous and as imbued with change. Drawing on Massey (2005), Mo's condition (of waiting) might be approached as a constellation of interrelations, that are biological, material, legal and affective. Importantly, these are also relations of power (in which the researcher is situated). To start understanding Mo's movement towards 'crazy,' which importantly involves more fully grasping the effects of waiting as a bordering technique, one must, to put it simply, understand that his now is also his mother's now. Furthermore, one must understand that this heterogenous and relational now cannot wait, as Mo says. While, as mentioned, he surely refers to the urgent needs of his family, I suggest that his statement prompts a more general consideration of the role of time and change when thinking of waiting. The urgency of his now points towards manifold futures, appearing in his struggle in Hamburg as, to paraphrase Chakrabarty 'a movement of existence, whose direction is futural' (2008: p. 251). This futural direction is visible in his will to work and to be a good son, his siblings' marriages, his mother's possible exhaustion. By grasping the relational character of waiting, the analytical optic might be opened for a consideration of time in terms of change and becoming in ways that complicate a reading of migrants' now from the perspective of a foretold future.

\section{'I cannot wait'}

In ethnographic research on irregular migration, waiting is often described as a condition of immobility and slowness (Griffiths et al., 2013; Andersson, 2014). Such a sense of slow time and existential immobility (Hage, 2009) was tangible in my fieldwork, especially in the camps and for people without a work permit (Mitrić, 2013; Drangsland, 2020). However, this temporalisation of time was deeply entangled with a sense of life not waiting. Indeed, an experience of the world's uncontrollable movement shaped my interlocutors' negotiations of spatial and existential immobility.

This entanglement of stasis and change, which also comes across in Mo's story, was forcefully present in my work with people from West Africa. With the exception of one older man, all were in the age of childbearing, as defined biologically (especially for women) and through gendered and heteronormative norms. A common theme in our conversations was a painful sense of time passing in terms of 'age going,' as one Ghanaian man put it, without having children because of an insecure legal and material situation. Their considerations recall Clark's (1999) research amongst Asante traders who, she argues, 'consider parenthood an essential element of both male and female gender and of personhood in the deepest sense' (1999: p. 417). I often discussed these issues with John (36), a Ghanaian IT-engineer who had lived unauthorised in Hamburg for 2 years, working two hours daily washing dishes. Reflecting about his own and other Ghanaians' situation as 'undocumented' (his words) in relation to the importance of parenthood, he once said: 'You have to be careful or else you can stay three or four years in 
this situation. You are not growing any younger. If you do not watch out, age will catch up with you.'

John's description of competing with the uncontrollable passing of time, of struggling not to be overhauled, but without the necessary means to do so, illustrates a common topic when my interlocutors described their (gendered) situation. It recalls Bourdieu's theorisations of waiting as a relation to time that occurs when people 'feel directly the breaking of the tacit collusion' (2000: p. 209) of their socially grounded life expectations and the course of the world (astronomical, social and biological processes) over which they have no or little power. Indeed, for John, the condition of waiting and 'watching out' in Hamburg, was in some sense a break of his 'normal' life in Ghana, where he had enjoyed a high rank in his congregation, and in periods earned good money from selling fish. However, for many people I worked with, who had been unemployed or worked in precarious conditions in Ghana or elsewhere, their situation in Hamburg formed part of 'a persistent circumstance' (Vigh, 2008: p. 9) of fragmentation and 'somatic, social and existential incoherence' (Vigh, 2008: p. 9), as Vigh puts it in his endeavour to rethink crisis away from its analytical association with rupture. Interestingly, after he had returned to Ghana and was struggling to find work and rebuild his life there, John told me: 'Life in here is no different from being undocumented in Hamburg. You still struggle to make a move; the only difference is you do not fear deportation,' subsequently explaining that to 'make a move,' means to become a parent/have children.

To highlight and question waiting's analytical association with a 'break,' is indeed important in the context of irregular migration, where, as already mentioned, this break easily is spatialised as a break with the territorial order of nation-states. There is however another aspect of this association of waiting with a break or rupture, that is important to my argument. John's practice of 'watching out' in Hamburg - which illustrates a general sense of alertness to the stakes of being 'undocumented' amongst my interlocutors points to how his condition of waiting, rather than a break with, is imbricated in the 'course of the world' (Bourdieu, 2000: p. 209) in terms of biological processes and social, normative and material relations (Massey, 2005). What fuels John's statements with such urgency - indeed, what defines his 'relation to time,' to use Bourdieu's words - is the embodied experience that life, when waiting, does not wait (see also Povinelli, 2011). When age 'catches up with him,' the future he has envisioned for himself (defined through fatherhood) will not be obtainable. The insight he conveys for thinking of waiting, I suggest, is that to grasp the stakes of people's struggles, the conceptualisation of waiting's now in relation to a future that is 'too slow in coming' (Bourdieu, 2000: p. 209) must be fused with an image of the future, or rather, futures, as always in becoming (Massey, 2005). This insight, furthermore, implies also recognising how people envision different futures for themselves; futures that are also differently spatialised (Vigh, 2008). 


\section{Concluding discussion: 'to read "lack" otherwise'}

Starting out with 'Mo's challenge' to my thinking, as he counters my quite-hesitant suggestion regarding Ausbildung, this chapter's objective has been to investigate the analytical optic of waiting in relation to methodological nationalism, and to unpack some ramifications of these imaginaries for how researchers understand migrants' now(s), their lives and struggles. Such an investigation, which involves being reflexive about one's (my) own research practices, is important in the context of a growing literature addressing migration through the analytical lens of waiting, and, furthermore, in relation to the prevalence of techniques of deferral in the bordering practices of Germany and the European Union (Bagelman, 2016; Will, 2018).

A core argument in this chapter is that the temporal structure of waiting, when used as an analytical optic in ethnographic work on irregular migration, makes it susceptible to methodological nationalism. I have identified this temporal structure as an orientation towards an (awaited) future and a related reading of the now in terms of lack in relation to this future. Employed in research on irregular migration, the analytical lens of waiting easily, I suggest, conjures up a story about migrants' now(s) as tending towards a future (waiting's end) that is spatialised as reinsertion into a nation-state.

Such a reading entails a reductive understanding of migrants' lives and might reinforce the nation-state frame. Stating this, I do not intend to divert attention away from how migrants' lives are conditioned by the absence of legal rights. Indeed, waiting gains analytical power exactly from its ability to capture how borders operate through deferral and tenuous future promises (Andersson, 2014; Bagelman, 2016; Barber \& Lem, 2018; Drangsland, 2019). In other words, as an analytic optic waiting enables ethnographers to see how insecurity and absence of legal rights materialise in migrants' lives as poverty, deteriorating health and legal and material obstacles for pursuing life projects. This context exhausts people, such as Mo. On the contrary, it is the acknowledgement of the importance of exploring the predicaments of those who are made waiting (Bourdieu, 2000) that makes it pertinent to thinking through waiting's temporal structure when putting it to analytical use.

I have suggested that one possible move to strengthen the analytical usefulness of waiting, by way of wrenching it out of the 'one story' structure, is to rethink the 'now' of waiting in terms of relationality and heterogeneity.

In some ways, to think waiting through a notion of relationality and heterogeneity could be framed as an act, to quote Chakrabarty out of context, to 'read "lack" otherwise' (2000: p. 34). In this chapter, I have used the notion of 'lack' to capture how the analytical imaginary of waiting, when used in migration research, might enforce a reading of migrants' 'now' as incomplete in relation to a future nation-state reinsertion. In ethnographic work with irregular migrants however, 'lack' also manifests materially in irregular migrants' 'nows,' in the sense that their lives are shaped through 
violent techniques of suspension, immobilisation and spatial confinement. To read lack otherwise in this sense, thus, would involve more fully grasping the predicaments of those made to wait. Indeed, to rethink the time of waiting in terms of temporal heterogeneity and relationality furthers the concept's analytical purchase for grasping the temporal dimensions of borders. It opens the analytical lens for the stakes of Mo's answer. This approach conjures into sight that because Mo's relationally lived now 'cannot wait,' the Ausbildungsduldung, with its suspension of work-income and prohibition to travel, implies for him not movement, but immobility. His life is made up of other trajectories than the 'lane' of the Ausbildungsduldung and of other futures than its foreseen end-station. In other words, Mo's answer makes visible that narrating the Ausbildungsduldung in terms of movement, not only works to conceal its effects of stasis and deferral, but that this imaginary paradoxically also occludes movement and change, in the sense of occluding the other trajectories, 'lanes' and movements that form his life.

This leads me to another meaning intended by my suggestion to read lack otherwise. For Chakrabarty (2000), to 'read "lack" otherwise,' was part of his critique against how historicism situated the Indian subject in terms of failure or lack in relation to modernity. To him, to read lack otherwise was certainly not a quest for better grasping lack and absence. On the contrary, it was a quest for an inversion; to read 'plenitude' and 'creativity' instead of lack (Chakrabarty, 2000: p. 34). In relation to waiting, to read lack otherwise in this sense, implies rethinking the now; from its conceptualisation as a 'not yet' of reinsertion into the national order, to a lived, relational and spatially embedded 'now.' To start understanding Mo's challenge, in other words, involves grasping the various ways he and other people struggle to make a life for themselves, in relation to violent border practices.

In different ways, both Chakrabarty and Massey highlight that to think time in terms of relationality and heterogeneity opens for questioning stories that posit people and places as heading towards an already defined, foretold future. To acknowledge (places and) people's lives as produced through interrelations and the now as inherently heterogeneous is, Massey (2005) argues, a condition for thinking politics at all, because it entails thinking the future as open (see also Chakrabarty, 2000; Grosz, 2011). Recalling this argument here, I am not making a claim for approaching irregular migrants' waiting in terms of becoming or potentiality in any celebratory manner. Indeed, Mo's condition of moving towards 'becoming crazy' shows how waiting is a 'corrosive' (Mulhall, 2014) and exhaustive condition. Peoples' ability to create liveable futures for themselves is unevenly distributed, and the relations through which people's lives are shaped are, as Massey (2005) argues, always relations of power. Yet, to acknowledge that things could be otherwise and to open up for the multiple ways of living and practicing futures is a prerequisite for a critical engagement with methodological nationalism (De Genova, 2013b). Here lies also a critical potential of opening the lens of waiting to temporal heterogeneity and relationality. 


\section{Acknowledgements}

I am grateful to the people I met in Hamburg for sharing their time with me and making my research possible. Thanks to the three editors, Christine M. Jacobsen, Marry-Anne Karlsen and Shahram Khosravi, for their thoughtful and immensely valuable comments on my chapter. Thanks to my colleagues in the WAIT project (Waiting for an uncertain future: the temporalities of irregular migration) for having valuable discussions on an early draft. All omissions and errors of course remain my responsibility.

\section{Notes}

1 The term 'now' is problematical. My choice to use 'now' comes from my effort to figure out what is at stake in Mo's reference to a 'now.' At the outset, I define it loosely as a lived present. My discussions of temporal imaginaries will add substance to this definition.

2 A 'Dublin decision' refers to the fact that other European Union countries are held responsible for their asylum applications according to the European Union Dublin Regulation.

3 In 2017, Ghana, Senegal, Albania, Bosnia-Hercegovina, Kosovo, Macedonia, Montenegro and Serbia were defined as secure third countries.

4 Afghans were the third largest group of asylum seekers in Germany in 2017. However, in the same year only around $45 \%$ of Afghans received some form of protection (Gesamtschutzquote; (cf. Deutscher Bundestag, 2018).

5 All conversations with Afghan and Syrian interlocutors were held in German, while my conversations with West-Africans were held in English.

6 My thinking here is inspired by Chakrabarty's (2000: p. 8) discussion of waiting and the 'not yet' of historicism.

7 The (politically contested) notion 'Spurwechsel' was used by politicians, humanitarian actors and public media in relation to Germany's first Skilled Immigration Act (Fachkräfteeinwanderungsgesetz), which was ratified by the Bundesrat in June 2019 as part of a package of migration laws (Migrationspaket). The notion describes more generally a policy that facilitates a transition from asylum to work as a path to a German residence permit, of which the Ausbildungsduldung is one of several measures (see e.g. Bojadzijev et al., 2016: p. 269, Will, 2018: p. 173).

8 For a discussion of such mechanism in Germany, see Mitrić (2013) and (Niess, 2018).

\section{References}

Amelina, A. \& Faist, T. (2012) De-naturalizing the national in research methodologies: Key concepts of transnational studies in migration. Ethnic and Racial Studies. 35, 1707-1724. DOI: 10.1080/01419870.2012.659273.

Andersson, R. (2014) Time and the migrant other: European border controls and the temporal economics of illegality. American Anthropologist. 116, 795-809. DOI: 10.1111/aman.12148.

Arendt, H. (1967) The origins of totalitarianism. London, Allen \& Unwin.

Auyero, J. (2011) Patients of the state: An ethnographic account of poor people's waiting. Latin American Research Review. 46, 5-29. DOI: 10.2307/41261368. 


\section{Kari Anne Drangsland}

Bagelman, J.J. (2016) Sanctuary city: A suspended state. New York, Palgrave Macmillan. DOI: 10.1057/9781137480385.0001.

Bakthin, M.M. (1981) The dialogic imagination: Four essays. Austin, University of Texas Press.

Barber, P.G. \& Lem, W. (2018) Migration, temporality, and capitalism: Entangled mobilities across global spaces. Cham, Palgrave Macmillan. DOI: 10.1007/9783-319-72781-3_1.

Bissell, D. (2007) Animating suspension: Waiting for mobilities. Mobilities. 2, 277 298. DOI: 10.1080/17450100701381581.

Bojadzijev, M., Mezzadra, S., Altenried, M., Höfler, L. \& Wallis, M. (2016) Migration und Logistik: Politiken und Vermittlung mobiler Arbeit. In: Forschungsbericht “Solidarität im Wandel?” Berliner Instituts für empirische Integrations- und Migrationsforschung(BIM), Humboldt-Universität zu Berlin. Available from: https:// www.integrationsbeauftragte.de/resource/blob/822390/316492/4752a527c9d904ff4ee5834e75867014/forschung-bim-solidaritaet-data.pdf?download=1. (accessed 25 March 2020).

Bourdieu, P. (2000) Pascalian meditations. Oxford, Polity Press.

Brücker, H., Jaschke, P., Keita, S. \& Konle-Seidl, R. (2019) 7/2019 Zum Gesetzentwurf der Bundesregierung über Duldung bei Ausbildung und Beschäftigung sowie zu den Anträgen der Fraktionen der FDP, Bündnis 90/DIE GRÜNEN und DIE LINKE. Available from: file://eir.uib.no/home6/st06069/Empiri/Lovverk\%20Tyskland/ Auslaenderbeschaeftigungsforederungsgesetz_2019/IAB_stellungsnahme_ lane \%20change.pdf. (accessed 29 April 2020).

Casas-Cortes, M., Cobarrubias, S., De Genova, N., Garelli, G., Grappi, G. \& Heller, C. (2015) New keywords: Migration and borders. Cultural Studies. 29, 55-87. DOI: 10.1080/09502386.2014.891630.

Castañeda, H. (2010) Deportation deferred. In: Peutz, N. \& De Genova, N. (eds.) The deportation regime: Sovereignty, space, and the freedom of movement. Durham, NC, Duke University Press, pp. 245-261.

Castañeda, H. (2012) 'Over-foreignization' or 'unused potential'? A critical review of migrant health in Germany and responses toward unauthorized migration. Social Science \& Medicine. 74, 830-838. DOI: 10.1016/j.socscimed.2011.05.024.

Chakrabarty, D. (2000) Provincializing Europe: Postcolonial thought and historical difference. Princeton, NJ, Princeton University Press.

Christensen, J.B. (2016) GUESTS OR TRASH: Iran's precarious policies towards the Afghan refugees in the wake of sanctions and regional war. Available from: https:// pure.diis.dk/ws/files/732765/DIIS_RP_2016_11_WEB.pdf. (accessed 4 February 2020).

Clark, G. (1999) Mothering, work, and gender in urban Asante ideology and practice. American Anthropologist. 101, 717-729. DOI: 10.1525/aa.1999.101.4.717.

Conlon, D. (2011) Waiting: Feminist perspectives on the spacings/timings of migrant (im) mobility. Gender, Place \& Culture. 18, 353-360. DOI: 10.1080/0966369X. 2011.566320.

De Genova, N. (2002) Migrant 'illegality' and deportability in everyday life. Annual Review of Anthropology. 31, 419-447. DOI: 10.1146/annurev.anthro. 31.040402.085432.

De Genova, N. (2013a) Spectacles of migrant 'illegality': The scene of exclusion, the obscene of inclusion. Ethnic and Racial Studies. 36, 1180-1198. DOI: 10.1080/ 01419870.2013.783710. 
De Genova, N. (2013b) 'We are of the connections': Migration, methodological nationalism, and 'militant research.' Postcolonial Studies. 16, 250-258. DOI: 10.1080/13688790.2013.850043.

Desjarlais, R.R. (1997) Shelter blues: Sanity and selfhood among the homeless. Philadelphia, University of Pennsylvania Press, Inc.

Deutscher Bundestag. (2018) Drucksache 19/1371(neu). Available from: http://dipbt. bundestag.de/dip21/btd/19/013/1901371.pdf. (accessed 13 February 2020).

Drangsland, K.A. (2020) Waiting as a redemptive state: The 'Lampedusa in Hamburg' and the offer from the Hamburg government. Time \& Society. 29, 1-22. DOI: 10.1177/0961463X19890989.

Drangsland, K.A. (2020) Bordering through recalibration. Exploring the temporality of the German 'Ausbildungsduldung'. EPC: Politics and Space. 0, 1-18 (pre-published). DOI: 10.1177/2399654420915611.

Forum Menschenrechte (2019) Sanktionen und Haft - zur Wirkung der aktuellen Gesetzesvorhaben im Asyl- und Aufenthaltsrecht. Available from: https:// www.forum-menschenrechte.de/wp-content/uploads/2019/04/190430-FMR_ Aktuelle-Gesetzgebungsverfahren-Kurz $\% \mathrm{C} 3 \%$ BCberblick.pdf. (accessed 11 September 2019).

Griffiths, M., Rogers, A. \& Anderson, B. (2013) Migration, time and temporalities: Review and prospect. COMPAS Research Papers.

Grosz, E. (2011) Becoming undone: Darwinian reflections on life, politics, and art. Durham and London, Duke University Press.

Hage, G. (2003) Against paranoid nationalism: Searching for hope in a shrinking society. Annandale, Pluto Press Australia.

Hage, G. (2009) Waiting out the crisis: On stuckedness and governmentality. In: Hage, G. (ed.) Waiting. Melbourne, Melbourne University Press, pp. 97-196.

Hage, G. (2018) Afterword. The ends of nostalgia: Waiting for the past-to-come. In: Janeja, M.K. \& Bandak, A. (eds.) Ethnographies of waiting: Doubt, hope and uncertainty. London and New York, Bloomsbury, pp. 203-208.

Hess, S. (2015) Jenseits des Kulturalismus. Ein Plädoyer für post-kulturalistische Ansätze in der kulturanthropologischen Migrationsforschung. In: Klückmann, M. \& Sparacio, S. (eds.) Spektrum Migration. Zugänge zur Vielfalt des Alltags. Tübingen, Tübingen Vereinigung für Volkskunde, pp. 37-64.

Hodges, M. (2008) Rethinking time's arrow: Bergson, Deleuze and the anthropology of time. Anthropological Theory. 8, 399-429. DOI: 10.1177/14634996 08096646.

Jacobsen, C.M. \& M.-A. Karlsen (2020) Introduction: Unpacking the temporalities of irregular migration. In C. M. Jacobsen, M.-A. Karlsen, \& S. Khosravi (eds.) Waiting and the Temporalities of Irregular Migration. London and New York: Routledge.

Jeffrey, C. (2008) Waiting. Environment and Planning D: Society and Space. 26, 954-958. DOI: 10.1068/d2606ed.

Karlsen, M.A. (2015) Precarious inclusion: Irregular migration, practices of care, and state bordering in Norway. PhD Thesis, University of Bergen, Norway.

Kelly, J. (1998) Time and the global: Against the homogeneous, empty communities in contemporary social theory. Development and Change. 29, 839-871. DOI: 10.1111/1467-7660.00101.

Khosravi, S. (2017) Precarious lives: Waiting and hope in Iran. Philadelphia, University of Pennsylvania Press. 
Klinke, I. (2013) Chronopolitics: A conceptual matrix. Progress in Human Geography. 37, 673-690. DOI: 10.1177/0309132512472094.

Lahad, K. (2017) A table for one A critical reading of singelhood, gender and time. Manchester, Manchester University Press.

Malkki, L.H. (1995) Refugees and exile: From 'refugee studies' to the national order of things. Annual Review of Anthropology. 24, 495-523. DOI: 10.1146/annurev. an.24.100195.002431.

Malkki, L.H. (2012) Purity and exile: Violence, memory, and national cosmology among Hutu refugees in Tanzania. Chicago and London, University of Chicago Press.

Massey, D. (2005) For space. London, Thousand Oaks, and New Delhi, Sage Publications.

Mitrić, D. (2013) In a castle between the earth and the sky: Bosnian refugees' narratives of exile under the German duldung temporary protection visa regime 1992-1998. PhD Thesis, La Trobe University, Australia.

Mountz, A. (2011) Where asylum-seekers wait: Feminist counter-topographies of sites between states. Gender, Place \& Culture. 18, 381-399. DOI: 10.1080/ 0966369X.2011.566370.

Mountz, A. \& Hyndman, J. (2006) Feminist approaches to the global intimate. Women's Studies Quarterly. 43, 446-463.

Mulhall, A. (2014) Dead time: Queer temporalities and the deportation regime. Social Text: Periscope. Time Binds. Available from: https://socialtextjournal.org/ periscope_article/dead-time-queer-temporalities-and-the-deportation-regime/. (accessed 6 February 2020).

Niess, B. (2018) Lampedusa in Hamburg Wie ein Protest die Stadt bewegte. Eine Ethnografie. Göttingen, Universitätsverlag Göttingen.

Nieswand, B. (2014) The burgers' paradox: Migration and the transnationalization of social inequality in southern Ghana. Ethnography. 15, 403-425. DOI: $10.1177 / 1466138113480575$.

Pedersen, M.A. (2012) A day in the Cadillac: The work of hope in urban Mongolia. Social Analysis: The International Journal of Social and Cultural Practice. 56, 136-151. DOI: 10.3167/sa.2012.560210.

Povinelli, E.A. (2011) Economies of abandonment: Social belonging and endurance in late liberalism. Durham and London: Duke University Press.

Pro Asyl. (2019) Hinweise für afghanische Flüchtlinge und ihre Berater*innen. Available from: https://www.proasyl.de/hintergrund/hinweise-fuer-afghanischefluechtlinge-und-ihre-beraterinnen/. (accessed 7 February 2020).

Ramsay, G. (2017) Impossible refuge: The control and constraint of refugee futures. London, Routledge.

Rotter, R. (2016) Waiting in the asylum determination process: Just an empty interlude? Time \& Society. 25, 80-101. DOI: 10.1177/0961463x15613654.

Salih, R. \& Richter-Devroe, S. (2018) Palestine beyond national frames: Emerging politics, cultures, and claims. South Atlantic Quarterly. 117, 1-20. DOI: 10.1215/00382876-4282019.

Scherschel, K. (2016) Citizenship by work? PROKLA. Zeitschrift für kritische Sozialwissenschaft. 46, 245-265.

Schultz, S. (2018) Demographic futurity: How statistical assumption politics shape immigration policy rationales in Germany. Environment and Planning D: Society and Space. 37, 644-662. DOI: 10.1177/0263775818772580. 
Sekino, H. (2010) Förderung der Rückkehr oder Integration der geduldeten Flüchtlinge? Die ambivalente Lage des Flüchtlingsschutzes. Journal of Political Science \& Sociology. 11, 69-89.

SPD. (2018) Pressemitteilung: Spurwechsel: Stichtagsregelung wäre die beste Lösung. Available from: https://www.spdfraktion.de/presse/pressemitteilungen/ spurwechsel-stichtagsregelung-waere-beste-loesung. (accessed 30 January 2020).

Starzmann, P. (2018) CSU gegen 'Spurwechsel' für abgelehnte Asylbewerber. Der Tagesspiegel Available from: https://www.tagesspiegel.de/politik/nach-vorstoss-vondaniel-guenther-csu-gegen-spurwechsel-fuer-abgelehnte-asylbewerber/22916882. html. (accessed 4 February 2020).

Vanstone, W.H. (2006) The stature of waiting. London, Darton, Longman and Todd.

Vigh, H. (2008) Crisis and chronicity: Anthropological perspectives on continuous conflict and decline. Ethnos. 73, 5-24. DOI: 10.1080/00141840801927509.

Voigt, C. (2018) Keine Spur vom Spurwechsel Ausbildungsduldung und Beschäftigungsduldung: Die Änderungen im 'Fachkräfteeinwanderungsgesetz': Gemeinnützige Gesellschaft zur Unterstützung Asylsuchender e.V. Available from: https:/ggua.de/fileadmin/downloads/Fachkraefte-Einwanderungsgesetz/Keine_ Spur_vom_Spurwechsel.pdf. (accessed 24 March 2020).

Voigt, C. (2020) Arbeitshilfe zum Thema Flucht und Migration Soziale Rechte für Flüchtlinge 3. aktualisierte Auflage 2020. Berlin, Deutscher paritätischer wohlfahrtsverband gesamtverband e. v. Available from: http://www.der-paritaetische. de/fileadmin/user_upload/Publikationen/doc/sozialleistungen-fluechtlinge-2019aufl3_web.pdf. (accessed 26 March 2020).

Walter, J.D. (2019) Flüchtlinge: Erst Asyl, dann Arbeit? Deutsche Welle. Available from: https://www.dw.com/de/flüchtlinge-erst-asyl-dann-arbeit/a-49092998. (accessed 03 January 2020).

Will, A.K. (2018) On "Genuine" and "Illegitimate" refugees: New boundaries drawn by discriminatory legislation and practice in the field of humanitarian reception in Germany. Social Inclusion. 6, 172-189. DOI: 10.17645/si.v6i3.1506.

Wimmer, A. \& Glick Schiller, N. (2002) Methodological nationalism and beyond: Nation-state building, migration and the social sciences. Global Networks. 2, 301-334. DOI: 10.1111/1471-0374.00043.

Zentraler Koordinierungsstab Flüchtlinge. (2017) Lagebild Flüchtlinge. Nr. 25/2017 Stand: 23.06.2017. 